\title{
Influence of Psychological, Anthropometric and Sociodemographic Factors on the Symptoms of Eating Disorders in Young Athletes ${ }^{1}$
}

\author{
Leonardo de Sousa Fortes ${ }^{2}$ \\ Universidade Federal de Juiz de Fora, Juiz de Fora-MG, Brazil \\ Sebastião de Sousa Almeida \\ Universidade de São Paulo, Ribeirão Preto-SP, Brazil \\ Maria Elisa Caputo Ferreira \\ Universidade Federal de Juiz de Fora, Juiz de Fora-MG, Brazil
}

\begin{abstract}
The aim of the current study was to analyse the influence of psychological, anthropometric and sociodemographic factors on the risk behaviours for eating disorders (ED) in young athletes. Participants were 580 adolescents of both sexes. We used the Eating Attitudes Test (EAT-26), the Body Shape Questionnaire and the Commitment Exercise Scale to assess the risk behaviours for ED, body image dissatisfaction (BD) and the degree of psychological commitment to exercise (DPCE), respectively. Participants' weight, height and skinfold thickness were measured. A multiple regression indicated that BD and percentage of fat significantly modulated $(p<.05)$ the variance of females' EAT-26 scores, whereas BD, DPCE, fat percentage, age, ethnicity and competitive level significantly explained $(p<.05)$ the variance of risk behaviours for males' ED. Thus, only BD influenced risk behaviours for ED in both sexes.
\end{abstract}

Keywords: eating behaviour, body image, athletes

\section{Influência de Fatores Psicológicos, Antropométricos e Sociodemográficos Sobre os Sintomas de Transtornos Alimentares em Jovens Atletas}

\begin{abstract}
Resumo: O objetivo do presente estudo foi analisar a influência de fatores psicológicos, antropométricos e sociodemográficos sobre os comportamentos de risco para transtornos alimentares (TAs) em jovens atletas. Participaram 580 adolescentes de ambos os sexos. Utilizou-se o Eating Attitudes Test (EAT-26), o Body Shape Questionnaire e a Commitment Exercise Scale para avaliar o comportamento de risco para TAs, a insatisfação com a imagem corporal (IC) e o grau de comprometimento psicológico ao exercício (GCPE), respectivamente. Peso, estatura e dobras cutâneas foram aferidos. Os achados da regressão múltipla evidenciaram que somente a IC e o percentual de gordura modularam significativamente $(p<0,05)$ a variância dos escores do EAT-26 no sexo feminino; enquanto entre os meninos, IC, GCPE, percentual de gordura, idade, etnia e nível competitivo explicaram significativamente $(p<0,05)$ a variância dos comportamentos de risco para TAs. Concluiu-se que somente a IC influenciou os comportamentos de risco para TAs em ambos os sexos.
\end{abstract}

Palavras-chave: comportamento alimentar, imagem corporal, atletas

\section{Influencia de los Factores Psicológicos, Antropométricos y Sociodemográficos Sobre los Síntomas de los Trastornos Alimentarios en Jóvenes Deportistas}

\begin{abstract}
Resumen: El objetivo fue analizar la influencia de factores psicológicos, antropométricos y sociodemográficos en los comportamientos de riesgo para TA en atletas jóvenes. Participantes fueron 580 adolescentes de ambos sexos. Se utilizó el Eating Attitudes Test (EAT-26), Body Shape Questionnaire y Commitment Exercise Scale para evaluar los comportamientos de riesgo para los TA, la insatisfacción con el imagen corporal (IC) y el grado de compromiso psicológico para ejercer (GCPE), respectivamente. Peso, talla y pliegues cutáneos se midieron. Los resultados de regresión múltiple mostraron que sólo el IC y el porcentaje de grasa modula de manera significativa $(p<0,05)$ la variación de las puntuaciones EAT-26 en las mujeres, mientras que entre los varones, IC, GCPE, porcentaje de grasa corporal, edad, etnia y nivel competitivo explicaron de manera significativa $(p<0,05)$ la variación de los comportamientos de riesgo para los TA. Se concluyó que sólo el IC influyó en los comportamientos de riesgo para los TA en ambos sexos.
\end{abstract}

Palabras clave: conducta alimentaria, imagen corporal, atletas

Eating disorders (ED) are psychiatric syndromes characterised by pathological control of body weight,

\footnotetext{
${ }^{1}$ Paper derived from the research dissertation of the first author with the guidance of the second author, which was defended within the Graduate Program in Physical Education of the Faculty of Physical Education and Sports, Federal University of Juiz de Fora, on December 16, 2011.

Support: National Council for Scientific and Technological Development (CNPq).

${ }^{2}$ Correspondence address:

Leonardo de Sousa Fortes. Rua Francisco da Cunha, 1340/1001. CEP 51020-041. Boa Viagem. Recife-PE, Brazil.

E-mail: leodesousafortes@hotmail.com
}

disturbances in perception of body shape and seriously disturbed eating behaviour (Filaire, Larue, \& Rouveix, 2011; Gomes, Legnani, Legnani, Gregory, \& Souza, 2010, Schaal et al., 2011; Scoffier, Maiano, \& D’Arripe-Longueville, 2010). The use of drugs (e.g., laxatives and diuretic) for weight loss, the self-induction of vomiting and the practices of strenuous physical exercise and food restriction are common in patients who have ED (Coelho, Soares, \& Ribeiro, 2010). Individuals without a clinical diagnosis of ED who present these behaviours are considered vulnerable to the development of these psychopathologies (Artioli, Scagliusi, Polacow, 
Gualano, \& Lancha-Junior, 2007; Perini, Vieira, Vigário, Oliveira, \& Ornellas, 2009; Sundgot-Borgen \& Torstveit, 2004), including athletes (De Bruin, Oudejans, \& Bakker, 2007; Gomes \& Silva, 2010; Holm-Denoma, Scaringi, Gordon, Van Orden, \& Joiner, 2009; Krentz \& Warschburger, 2011). Research suggests that adolescent athletes are highly susceptible to the development of risk behaviours for ED (De Bruin et al., 2007; Forts \& Ferreira, 2011).

There are several factors that can influence the risk for developing ED. According to Conti, Frutuoso and Gambardella (2005), dissatisfaction with body image is a primary factor. Another factor is a preoccupation with weight and physical appearance (Carvalho, Cataneo, Galindo \& Malfará, 2005; Conti, Cordás, \& Latorre, 2009). Studies have shown that dietary inadequacy is a result of dissatisfaction with body image (Peden, Stiles, Vandehey, \& Diekhoff, 2008; Scoffier et al., 2010).

In addition to dissatisfaction with body image, morphological inadequacy can lead to disordered eating in young (Hagmar, Hirchsberg, Beglund, \& Beglund, 2008), given that higher body mass indices (BMI) and fat percentages have been associated with abnormal eating habits (De Bruin et al., 2007). Moreover, a high degree of psychological impairment with regard to exercise may be related to the risk of ED. Modolo et al. (2011) suggest that a psychological addiction to exercise can be a consequence of individuals' depreciation of their own bodies, which may impair eating habits.

Individuals' economic status and ethnicity may influence the initiation of risk behaviour for ED. Researchers argue that this risk is more prevalent for the highest strata of society (Dunker, Fernandes, \& Carreira-Filho, 2009) and for individuals of white ethnicity (Pernick et al., 2006; Sampei, Sigulem, Novo, Juliano, \& Colugnati, 2009). In athletes, the risk of developing abnormal eating habits may be higher when compared to that of the general population (Filaire et al., 2011; Fortes, Paes, Amaral, \& Ferreira, 2012; Schaal et al., 2011). Krentz and Warschburger (2011) and Schaal et al. (2011) emphasise that the sporting arena has leveraged agents for such risks, with the competitive level considered as one of them. According to Holm-Denoma et al. (2009) and Peden et al. (2008), food inadequacy is most prevalent in young athletes who are competing at high levels due to pressure imposed by coaches, parents and sponsors.

Studies have shown that the prevalence of risk behaviours for ED range from 5\% to $40 \%$ in athletes (Coelho et al., 2010; Filaire et al., 2011; Gomes \& Silva, 2010; HolmDenoma et al., 2009; Krentz \& Warschburger, 2011; Schaal et al., 2011; Torstveit \& Sundgot-Borgen, 2005). Females may be more affected by these behaviours than males (De Bruin et al., 2007; Perini et al., 2009). According to Fortes and Ferreira (2011), females are more concerned with reducing body weight compared to males. However, surveys of males are scarce regarding this topic. To date, no studies have examined the influence of psychological, anthropometric and sociodemographic variables on the risk factors for ED in competitive athletes. Therefore, the aim of the current study was to analyse the influence of psychological (i.e., dissatisfaction with body image and the psychological commitment to exercise), anthropometric (i.e., body fat percentage and BMI) and sociodemographic (i.e., economic status, ethnicity, competitive level and chronological age) factors on risk behaviours for ED in young athletes.

\section{Method}

\section{Participants}

This was a cross-sectional study that was conducted in the cities of Rio de Janeiro/RJ, Três Rios/RJ, Barbacena/MG and Juiz de Fora/MG with young athletes of both sexes. Participants were 620 adolescents between the ages of ten and nineteen years from five clubs. However, 40 participants were excluded from the study due to not completing the questionnaires or anthropometric measurements in their entirety. A total of 580 athletes were included from the following sports: track and field ( $n=10)$, basketball $(n=72)$, fencing $(n=8)$, soccer $(n=271)$, artistic gymnastics $(n=14)$, handball $(n=36)$, judo $(n=14)$, swimming $(n=64)$, synchronised swimming $(n=18)$, water polo $(n=16)$, diving $(n=10)$, tae-kwon-do $(n=10)$, triathlon $(n=14)$ and volleyball $(n=22)$. Participants were selected according to the following criteria: (a) available to answer questionnaires and perform anthropometric measurements, (b) between the ages of ten and nineteen years, (c) systematically training for their respective sport at least five times a week, with a minimum of one hour per session, and (d) participating at a tournament regional or more competitive level at the time of data collection. To select the participants, we adopted the technique of simple random sampling.

For participants who were younger than eighteen years of age, their guardians signed a consent form (ICF) that explained the objectives and procedures of the study and allowed for voluntary participation in child research. Anonymity of all research subjects was guaranteed.

\section{Instruments}

The following instruments and measures were used:

Questionnaire Eating Attitudes Test (EAT-26). This instrument assesses the risk factors for ED, including dietary restriction, binge eating, purging behaviours and environmental pressure regarding food intake. The EAT-26 consists of twenty-six items on a Likert response scale, ranging from 0 to $3(3=$ always, $2=$ often $/$ seldom, $1=$ often $/$ rarely/almost never and $0=$ never), with the exception of question 25 , which has a reversed scale $(0=$ always/often/ seldom, $1=$ rarely, $2=$ almost never, and $3=$ never . A score equal to or greater than 20 reflects that individuals are at risk for ED. The versions used in this study were validated 
(Bighetti, Santos, Santos, \& Ribeiro, 2004; Fortes, Ferreira, Amaral, Conti, \& Cordás, in press) with young females and males, with internal consistencies of .82 and .87 , respectively. In this sample, we calculated the Cronbach's alphas as .89 for females and .92 for males.

Body Shape Questionnaire (BSQ). This self-administered instrument assesses dissatisfaction with body image by measuring individuals' frequency of preoccupation with their weight and physical appearance. The BSQ consists of 34 items on a Likert-type response scale, ranging from 0 to $6(0=$ never and $6=$ always). The final score is the sum of the scores for all of the questions, with a higher score reflecting greater body dissatisfaction. Additionally, this questionnaire provides classification levels regarding individuals' dissatisfaction with their body image. Accordingly, having a score that is greater than or equal to 80 subjects' scores indicates dissatisfaction with one's weight and body appearance. Conti et al. (2009) validated the version of this questionnaire used in the current study with Brazilian adolescents. An internal consistency analysis revealed alphas of .96 for both sexes, and the mean correlation coefficients between the test-retest reliability scores ranged from .89 to .91 for females and males, respectively. The Cronbach's alphas for this sample were .91 for females and .92 for males.

Commitment Exercise Scale (CES). This instrument analyses individuals' psychological commitment to exercise. Teixeira, Hearst, Matsudo, Cordás and Conti (2011) translated, adapted and validated this instrument in Portuguese and referred to it as the Dedication Scale Exercise, which had a Cronbach's alpha of .79. The CES assesses the degree to which feelings of well-being are modulated by exercise, the maintenance of exercise during adverse conditions and the degree of interference that physical activity has on individuals' social commitments. This is a visual analogue scale that consists of eight questions, ranging from 0 to $155 \mathrm{~mm}$. There is a maximum score of $1,240 \mathrm{~mm}$. The present sample had Cronbach's alphas of .85 and .88 for females and males, respectively, reflecting the sample's internal consistency.

Calculation of percentage offat. The body fat percentage (\% BF) was estimated using the doubly indirect method, which measures the triceps and subscapular skinfolds. We used Slaughter et al.'s (1988) protocol, which was created for use with adolescent populations, to determine this estimate. The measurements were performed rotationally and conducted three times to provide average values. In addition, the measurements were performed by the same evaluator to avoid inter-appraisal errors.

Body weight. Body mass was measured using a porTable digital Tanita scale with $100 \mathrm{~g}$ precision and a maximum capacity of $200 \mathrm{~kg}$.

Height. Height was measured using a porTable stadiometer that was accurate to $0.1 \mathrm{~cm}$ with a maximum height of $2.20 \mathrm{~m}$. Welmy is the brand often used to measure the stature of athletes. We calculated participants' body mass index (BMI) from the height and weight measurements $\left[\mathrm{BMI}=\right.$ body mass $(\mathrm{kg}) /$ height $\left.\left(\mathrm{m}^{2}\right)\right]$.
Brazil Economic Classification Criteria. These criteria were developed by the Brazilian Association of Research Companies (ABEP, 2003) to assess families' economic levels. The Economic Classification Criterion Brazil emphasises its ability to estimate the purchasing power of urban individuals and families. It does not rely on the pretence of classifying a population in terms of social classes. This instrument measures the number of comfort items (e.g., car, refrigerator, television, etc.) acquired and identifies the educational level of the head of the household. Scores range from zero to thirty-four, with higher scores reflecting greater economic levels.

Demographics. A qualitative questionnaire was used to assess demographic data, such as age, ethnicity (e.g., white, black or yellow), competitive level (e.g., regional, state or national) and training system (e.g., number of training hours per day).

\section{Procedure}

Data collection. Data collection occurred during the months of March, April and May of 2011 in rooms provided by the clubs that participated in the research. Parents' permission was obtained one week before the questionnaires and anthropometric measurements were distributed to the ICF athletes who were younger than 18 years. The following week, the researchers distributed the instruments and performed the anthropometric measurements for the athletes who had signed the consent form.

After a brief explanation of the research, participants completed the questionnaires individually. The average time to complete the questionnaires was 35 minutes. Anthropometric measurements (i.e., weight, height and skinfolds) were conducted immediately after this first time.

Data analysis. Means, standard deviations and frequencies were used to describe the study variables. Inferential statistics were used to report the internal consistencies (i.e. Cronbach's alphas) of the questionnaires. We applied the Kolmogorov-Smirnov test to evaluate the normality of the research variables. Parametric (i.e., Independent Student's t) and nonparametric (i.e., Mann Whitney) tests were used to compare the data between the sexes. In addition, we conducted a stepwise multiple linear regression to determine the influence that the study variables (i.e., dissatisfaction with body image, psychological commitment to exercise, anthropometry, age, economic status, ethnicity and competitive level) exerted on the risk behaviours for ED in young athletes. Data analysis was performed using SPSS 17.0 software, adopting a significance level of $5 \%$.

\section{Ethical Considerations}

This study was conducted only after receiving approval from the Ethics Committee for Human Research at the Universidade Federal de Juiz de Fora (Protocol - 2149.209.2010; project 232/2010), according to the Resolution no. 196/96, of the National Council of Health. 


\section{Results}

Results revealed that the prevalence rates related to risk behaviours for ED were $18.1 \%$ for female athletes and $14.4 \%$ for male athletes. Similarly, the frequencies of dissatisfaction with body image were higher for females (38.8\%) than males (14.4\%).

Table 1 presents the descriptive data scores (i.e., means and standard deviations) for the EAT-26, BSQ, ABEP and CES, as well as the values for the BMI, body fat percentage, age, training history and scheme of the study sample according to the sex. Table 2 presents the distributions of absolute and relative frequencies for the competitive levels and ethnicities of the study sample according to sex.

Table 1

Means and Standard Deviations for the Study Variables According to Sex

\begin{tabular}{lcccc}
\hline \multirow{2}{*}{ Variable } & \multicolumn{2}{c}{ Female $(n=116)$} & \multicolumn{2}{c}{ Male $(n=464)$} \\
\cline { 2 - 5 } & $M$ & $S D$ & $M$ & $S D$ \\
\hline EAT-26 & 11.89 & 7.92 & 11.59 & 11.78 \\
BSQ* $^{*}$ & 75.45 & 28.81 & 59.75 & 21.90 \\
$\mathrm{CES}$ & 676.90 & 219.17 & 685.61 & 228.42 \\
$\mathrm{BMI} \dagger$ & 20.43 & 3.17 & 21.28 & 2.90 \\
$\% \mathrm{BF} \dagger$ & 23.03 & 6.22 & 18.43 & 7.26 \\
$\mathrm{ABEP}$ & 21.25 & 4.70 & 20.59 & 4.64 \\
Age & 14.52 & 2.00 & 15.05 & 2.02 \\
$\mathrm{RT}$ (hours/day) & 2.21 & 0.34 & 2.54 & 0.48 \\
TH (years) & 2.77 & 1.05 & 3.19 & 1.41 \\
\hline
\end{tabular}

Note. EAT-26 = Eating Attitudes Test; BSQ = Body Shape Questionnaire; CES = Commitment Exercise Scale; BMI = Body Mass Index; $\%$ BF $=$ Percentage of body fat; ABEP = Brazil Economic Classification Criteria; $\mathrm{RT}=$ Training; $\mathrm{TH}=$ History of training.

$\dagger p<.05$ between the sexes valued by an independent student $\mathrm{t}$ test.

$* p<.05$ between the sexes valued by a Mann Whitney test.

Table 2

Frequency Distributions for Ethnicity and Competitive Level in Young Athletes According to Sex

\begin{tabular}{lcc}
\hline \multirow{2}{*}{ Variable } & \multicolumn{2}{c}{ AF (\%) } \\
\cline { 2 - 3 } Ethnicity & $93(80.2)$ & $289(62.2)$ \\
White & $19(16.4)$ & $141(30.4)$ \\
Black & $4(3.4)$ & $32(6.9)$ \\
Yellow & & \\
CL & $24(20.7)$ & $242(52.2)$ \\
Regional & $22(19)$ & $107(23.1)$ \\
State & $70(60.3)$ & $115(24.8)$ \\
$\quad$ National & Fale \\
\hline Note. AF = Absolute Frequency; $\mathrm{CL}=$ Competitive Level.
\end{tabular}

Regarding the influence of the independent variables on the risk behaviours for $\mathrm{ED}$, the results of a multiple regression showed that only dissatisfaction with body image
$(40 \%)$ and fat percentage (3\%) significantly modulated $(p<.05)$ the variance for the EAT-26 scores in females (Table 3), whereas dissatisfaction with body image (12\%), the degree of psychological impairment to exercise (17\%), fat percentage $(3 \%)$, age $(4 \%)$, ethnicity $(1 \%)$ and competitive level $(3 \%)$ significantly explained $(p<.05)$ the variance in risk behaviours for ED in males (Table 4). The interaction of all of the independent variables influenced $31 \%$ of the EAT-26 scores in females and $25 \%$ in males.

Table 3

Multiple Linear Regression Results for Young Female Athletes

\begin{tabular}{lllcc}
\hline Variable & $R$ & $R^{2}$ & $R^{2}$ adjusted & $p$ \\
\hline BSQ & .63 & .40 & .39 & $<.01$ \\
CES & .18 & .03 & .02 & $<.09$ \\
BMI & .15 & .02 & .02 & $<.09$ \\
\%BF & .18 & .03 & .02 & $<.05$ \\
ABEP & .11 & .01 & .004 & $<.24$ \\
Age & .01 & .001 & .009 & $<.91$ \\
Ethnicity & .04 & .02 & .007 & $<.66$ \\
CL & .12 & .01 & .005 & $<.21$ \\
All & .56 & .31 & .24 & $<.01$ \\
\hline Note. EAT-26 = Eating Attitudes Test; BSQ $=$ Body Shape \\
Questionnaire; CES = Commitment Exercise Scale; BMI = Body \\
Mass Index; \%BF = Percentage of body fat; ABEP = Brazil \\
Economic Classification Criteria; CL = Competitive Level.
\end{tabular}

Table 4

Multiple Linear Regression Results for Young Male Athletes

\begin{tabular}{lcccc}
\hline Variable & $R$ & $R^{2}$ & $R^{2}$ ajusted & $p$ \\
\hline BSQ & .34 & .12 & .12 & $<.01$ \\
CES & .41 & .17 & .16 & $<.01$ \\
BMI & .06 & .004 & .001 & $<.20$ \\
\%BF & .16 & .03 & .02 & $<.01$ \\
ABEP & .03 & .001 & .001 & $<.48$ \\
Age & .20 & .04 & .04 & $<.01$ \\
Ethnicity & .10 & .01 & .008 & $<.03$ \\
CL & .18 & .03 & .03 & $<.01$ \\
All & .50 & .25 & .19 & $<.01$ \\
\hline
\end{tabular}

Note. EAT-26 = Eating atitudes test; $\mathrm{BSQ}=$ Body shape questionnaire; CES = Commitment Exercise Scale; BMI = Body mass index; $\% \mathrm{BF}=$ Percentage of body fat; $\mathrm{ABEP}=$ Brazil Economic Classification Criteria; $\mathrm{CL}=$ Competitive Level.

\section{Discussion}

The aim of the current study was to analyse the influence of psychological (i.e., dissatisfaction with body image and the degree of psychological impairment to exercise), anthropometric (i.e., body fat percentage and BMI) and sociodemographic (i.e., economic status, ethnicity, competitive level and chronological age) factors on risk behaviours for ED in young athletes. Studies have examined statistically 
significant associations between dissatisfaction with body image (Coelho et al., 2010), psychological commitment addiction to exercise (Modolo et al., 2011), anthropometric measurements (i.e., BMI and adiposity) (De Bruin et al., 2007), ethnicity (Pernick et al., 2006) and competitive level (HolmDenoma et al., 2009; Peden et al., 2008) and risk factors for ED in athletes. However, until now, no studies have examined the variance in eating attitudes that are characteristics of ED in young athletes, especially in a Brazilian population.

The results of the current study demonstrate the significant influence of dissatisfaction with body image and body fat percentage on the risk behaviours for ED in females. In contrast, for males, dissatisfaction with body image, body fat percentage and other variables (i.e., the degree of psychological commitment to exercise, age, ethnicity and competitive level) showed statistically significant influences on their EAT- 26 scores.

For females, the current study's findings are consistent with findings and hypotheses of other authors (Coelho et al., 2010; De Bruin et al., 2007; Krentz \& Warschburger, 2011; Sundgot-Borgen \& Torstveit, 2004). Thus, dissatisfaction with body image may be the factor that best explains the emergence of risk behaviours for ED in females (Peden et al., 2008). Krentz and Warschburger (2011) suggest that depreciation of weight and physical appearance is highly prevalent among female athletes and may lead to psychological problems, such as ED. In addition, research indicates that adolescence may be the developmental phase with the highest levels of body dissatisfaction (De Bruin et al., 2007; Sundgot-Borgen \& Torstveit, 2004). This may explain the large influence of dissatisfaction with body image scores of the EAT-26 in this study, as this sample was composed of teenage athletes. On the other hand, studies have shown conflicting results (Perini et al., 2009; Reinking \& Alexander, 2005; Torstveit \& Sundgot-Borgen, 2005), with low levels of body dissatisfaction associated with inappropriate eating habits in female competitors. One possibility is that the body fat percentage of participants may have influenced the findings. According to De Bruin et al. (2007), females are highly concerned with morphological aspects that are depreciated in Western culture, such as body fat. In the present study, we found that fat percentage explained $3 \%$ of the variance in the EAT- 26 scores in females. It is important to note that this finding may be related to characteristics of the present sample, as research suggests that body fat in females increases during adolescence (Slaughter et al., 1988). Therefore, adolescents may adopt eating behaviours similar to ED to reduce their body fat.

In addition, researchers have shown that economic level, ethnicity and level of sporting competition may negatively affect the eating behaviours of young athletes (Pernick et al., 2006; Schaal et al., 2011). However, in the current study, statistical significance was not evident for these variables in the multiple regression model. Yet, other factors may negatively influence the eating habits of female athletes, such as selfesteem, perfectionism, emotional intelligence and depression.
For males, the results of this study are consistent with those from previous studies (Baum, 2006; Costarelli \& Stamou, 2009; Filaire, Rouveix, Pannafieux, \& Ferrand, 2007; Holm-Denoma et al., 2009; Silva, Gomes, \& Martins, 2011). Dissatisfaction with body image explained $12 \%$ of the variance in the risk factors for ED for males. Although these findings are consistent with previous scientific literature, it is worth noting that the influence of dissatisfaction with body image on the EAT-26 scores in male athletes may be related to characteristics of the study sample. Research shows that adolescents are more dissatisfied with their bodies compared to other age group (Filaire et al., 2011; Silva et al., 2011). The variable that best explained the risk factors for ED among males was the degree of psychological impairment to exercise (17\%), although fat percentage, age, ethnicity and competitive level also influenced the EAT-26 scores. Thus, dedication to exercise may be a predisposing factor for the initiation of risk behaviours for ED in young men. Modolo et al. (2011) suggest that the psychological addiction to physical training originates in dissatisfaction with body image, which, in turn, negatively influences unhealthy eating habits. According to a number of authors, this dependence may also be present in sports (Modolo et al., 2011; Sundgot-Borgen \& Torstveit, 2010). One possibility is that male athletes feel pressured by coaches, parents and sponsors to optimise their yields, believing that increasing the frequency and volume of sports training may achieve better results (Holm-Denoma et al., 2009; Peden et al., 2008). However, this exaggerated increase in the frequency and volume of physical training is inversely proportional to maximising sport performance (SundgotBorgen \& Torstveit, 2010). Thus, these young athletes may develop eating behaviours that are considered pathological in an attempt to achieve high peak athletic performance (Filaire et al., 2007; Silva et al., 2011).

In addition to the level of commitment to exercise, other variables modulated the risk behaviours for ED among male athletes. The fat percentage of fat explained $3 \%$ of the variance in the EAT- 26 scores, whereas age, ethnicity and competitive level influenced $4 \%, 1 \%$ and $3 \%$, respectively. Male athletes may not be concerned with morphological aspects. The results from previous studies have shown the lack of influence of anthropometric measurements on pathological eating behaviours in males (Filaire et al., 2007; Forts \& Ferreira, 2011). Some authors claim that BMI may negatively influence eating habits (Filaire et al., 2007; Torstveit \& Sundgot-Borgen, 2005); however, this trend was not confirmed in the current study.

One variable that has been widely discussed regarding its influence on the behaviour of athletes is their competitive level. Studies have shown that higher degrees of competitiveness reflect the larger negative influences on eating habits (HolmDenoma et al., 2009; Krentz \& Warschburger, 2011); however, there is little empirical evidence to support this argument (Peden et al., 2008). Despite the statistical significance identified in the present study, participants' competitive level 
explained only $3 \%$ of the variance in risk behaviours for ED in males. However, methodological differences in previous research cause comparisons between studies to be difficult.

Participants' ethnicity and age also significantly modulated risk behaviours for ED among males. However, no data from previous studies are available yet regarding these variables with athletes. Other factors, such as extrinsic pressures, the sport and the type of uniform, may better explain the variance in risk behaviour for ED in male athletes. Fortes and Ferreira (2011) argue that athletes in sports with aesthetic features, which emphasise a uniform's body shape, may be more susceptible to the onset of risk behaviours for ED.

The findings of the current study should be interpreted with caution, as the limitations are the following:

1. We used the doubly indirect method to estimate body fat, which is subject to measurement errors. However, this method is recommend for large samples, as in the present study, given that it has easily applicable tools and a low financial burden (Peden et al., 2008; Sundgot-Borgen \& Torstveit, 2004).

2. The design of transversal does not permit causality inferences to be posited, meaning that there is no way to assess the intensity and direction of the associations found between the outcome and the independent variables. In general, this is a limitation of cross-sectional studies, which present a snapshot of the research context.

3. Participants' mood states (e.g., anger, stress, anxiety and fatigue) were not controlled for in the statistical analysis of this research. Research suggests that negative mood states may predispose athletes to eating behaviours similar to ED (Gomes \& Silva, 2010; Silva et al., 2011). Therefore, the results of the current study may contribute important information to the literature and they deserve to be compared and discussed in in future studies.

\section{Final Considerations}

The results of this study allow us to conclude that dissatisfaction with body image and fat percentage influenced risk behaviour for ED in both sexes. However, compared with females, other variables influenced the risk behaviours for ED in young male athletes. The factors that negatively influence disordered eating in athletes may differ between the sexes. Dissatisfaction with body image may be the primary variable affecting females, yet the type of sport practiced may modulate these behaviours to a greater extent. In males, several factors influenced their EAT-26 scores.

Among athletes, particularly females, a number of unknown factors that have not been studied may explain the risk factors for ED and these factors should be examined in the near future. Psychological variables, such as emotional intelligence, perfectionism, self-esteem and depression, may better explain the variance in risk behaviour for ED.

Furthermore, we argue that studies should include perceptual ratings of body size in young athletes, as the deleterious health risks associated with public eating behaviours may result from distortions in body size. In
Brazil, such studies are scarce, primarily because software assessing body perception in athletes is not available.

\section{References}

Artioli, G. G., Scagliuse, F. B., Polacow, V. O., Gualano, B., \& Lancha-Júnior,A.H. (2007). Magnitude e métodos de perda rápida de peso em judocas de elite. Revista de Nutrição, 20(3), 307-315. doi:10.1590/S1415-52732007000300009

Associação Brasileira de Empresas de Pesquisa. (2003). Critério de Classificação Econômica Brasil. Dados com base no Levantamento Sócio Econômico - 2000 - IBOPE. Retrieved from http://www.abep.org/novo/ Content.aspx? ContentID $=302$

Baum, A. (2006). Eating disorders in the male athlete. Sports Medicine, 36(1), 1-6. doi:10.2165/00007256-200636010-00001

Bighetti, F., Santos, C. B., Santos, J. E., \& Ribeiro, R. P. P. (2004). Tradução e avaliação do Eating Attitudes Test em adolescentes do sexo feminino de Ribeirão Preto, São Paulo. Jornal Brasileiro de Psiquatria, 53(6), 339-346.

Carvalho, A. M. P., Cataneo, C., Galindo, E. M. C., \& Malfará, C. T. (2005). Auto conceito e imagem corporal em crianças obesas. Paidéia (Ribeirão Preto), 15(30), 131-139. doi:10.1590/S0103-863X2005000100014

Coelho, G. M. O., Soares, E. A., \& Ribeiro, B. G. (2010). Are female athletes at increased risk for disordered eating and its complications? Appetite, 55(3), 379-387. doi:10.1016/j.appet.2010.08.003

Conti, M. A., Cordás, T. A., \& Latorre, M. R. D. O. (2009). A study of the validity and reliability of the Brazilian version of the Body Shape Questionnaire (BSQ) among adolescents. Revista Brasileira de Saúde Materna e Infantil, 9(3), 331-338. doi:10.1590/S1519-38292009000300012

Conti, M. A., Frutuoso, M. F. P., \& Gambardella, A. M. D. (2005). Excesso de peso e insatisfação corporal em adolescentes. Revista de Nutrição, 18(4), 491-497. doi:10.1590/S1415-52732005000400005

Costarelli, V., \& Stamou, D. (2009). Emotional intelligence, body image and disordered eating attitudes in combat sport athletes. Journal of Exercise Science Fitness, 7(2), 104-111. doi:10.1016/S1728-869X(09)60013-7

De Bruin, A. P., Oudejans, R. R. D., \& Bakker, F. C. (2007). Dieting and body image in aesthetic sports: A comparison of Dutch female gymnasts and non-aesthetic sport participants. Psychology of Sport and Exercise, 8(4), 507-520. doi:10.1016/j.psychsport.2006.10.002

Dunker, K. L. L., Fernandes, C. P. B., \& Carreira-Filho, D. (2009). Influência do nível socioeconômico sobre comportamentos de risco para transtornos alimentares em adolescentes. Jornal Brasileiro de Psiquiatria, 58(3), 156-161. doi:10.1590/S0047-20852009000300003

Filaire, E., Larue, J., \& Rouveix, M. (2011). Eating behaviours in relation to emotional intelligence. International Journal of Sports Medicine, 32(4), 309-315. doi:10.1055/s-0030-1269913 
Filaire, E., Rouveix, M., Pannafieux, C., \& Ferrand, C. (2007). Eating attitudes, perfectionism and body-esteem of elite male judoists and cyclists. Journal of Sports Science and Medicine, 6(1), 50-57.

Fortes, L. S., \& Ferreira, M. E. C. (2011). Comparação da insatisfação corporal e do comportamento alimentar inadequado em atletas adolescentes de diferentes modalidades esportivas. Revista Brasileira de Educação Física e Esporte, 25(4), 707-716. doi:10.1590/S1807-55092011000400014

Fortes, L. S., Ferreira, M. E. C., Amaral, A. C. S., Conti, M. A., \& Cordás, T. A. (in press). Qualidades psicométricas do Eating Attitudes Test (EAT-26) para a população adolescente brasileira masculina. Psicologia: Reflexão e Crítica.

Fortes, L. S., Paes, S. T., Amaral, A. C. S., \& Ferreira, M. E. C. (2012). Insatisfação corporal e comportamento alimentar inadequado em jovens nadadores segundo níveis econômicos e competitivos. Jornal Brasileiro de Psiquiatria, 61(1), 20-24. doi:10.1590/S0047-20852012000100005

Gomes, J. P., Legnani, E., Legnani, R. F. S., Gregório, N. P., \& Souza, R. K. (2010). Associação entre comportamento alimentar, consumo de cigarro, drogas e episódios depressivos em adolescentes. Revista de Nutrição, 23(5), 755-762. doi:10.1590/S1415-52732010000500006

Gomes, R., \& Silva, L. (2010). Desordens alimentares e perfeccionismo: Um estudo com atletas portugueses. Psicologia em Revista, 16(3), 469-489.

Hagmar, M., Hirchsberg, A. L., Berglund L., \& Berglund, B. (2008). Special attention to the weight-control strategies employed by Olympic athletes striving for leanness is required. Clinical Journal of Sport Medicine, 18(1), 5-9. doi:10.1097/JSM.0b013e31804c77bd

Holm-Denoma, J. M., Scaringi, V., Gordon, K. H., Van Orden, K. A., \& Joiner, T. E., Jr. (2009). Eating disorder symptoms among undergraduate varsity athletes, club athletes, independent exercisers, and nonoexercises. International Journal of Eating Disorders, 42(1), 47-53. doi:10.1002/eat.20560

Krentz, E. M., \& Warschburger, P. (2011). Sports-related correlates of disordered eating in aesthetic sports. Psychology of Sport and Exercise, 12(4), 375-382. doi:10.1016/j.psychsport.2011.03.004

Modolo, V. B., Antunes, H. K. M., Gimenez, P. R. B., Santiago, M. L. M., Tufik, S., \& Mello, M. T. (2011). Negative addiction to exercise: Are there differences between genders? Clinics, 66(2), 255-260. doi:10.1590/S1807-59322011000200013

Peden, J., Stiles, B. L., Vandehey, M., \& Diekhoff, G. (2008). The effects of external pressures and competitiveness on characteristics of eating disorders and body dissatisfaction. Journal of Sport and Social Issues, 32(4), 415-429. doi:10.1177/0193723508325638
Pernick, Y., Nichols, J. F., Rauh, M. J., Kern, M., Ji, M., Lawson, M. J., \& Wifley, D. (2006). Disordered eating among a multi-racial/ethnic sample female high-school athletes. Journal of Adolescence Health, 38(4), 689-695. doi:10.1016/j.jadohealth.2005.07.003

Perini, T. A., Vieira, R. S., Vigário, P. S., Oliveira, G. L., Ornellas, J. S., \& Oliveira, F. P. (2009). Transtorno do comportamento alimentar em atletas de elite de nado sincronizado. Revista Brasileira de Medicina do Esporte, 15(1), 54-57. doi:10.1590/S1517-86922009000100012

Reinking, M. F., \& Alexander, L. E. (2005). Prevalence of disordered-eating behaviors in undergraduate female collegiate athletes and nonathletes. Journal of Athletic Training, 40(1), 47-51.

Sampei, M. A., Sigulem, D. M., Novo, N. F., Juliano, Y., \& Colugnati, F. A. B. (2009). Atitudes alimentares e imagem corporal em meninas adolescentes de ascendência nipônica e caucasiana em São Paulo (SP). Jornal de Pediatria, 85(2), 122-128. doi:10.1590/S0021-75572009000200007

Schaal, K., Tafflet, M., Nassif, H., Thibault, V., Pichard, C., Alcotte, M., Toussaint, J. F. (2011). Psychological balance in high level athletes: Gender-based differences and sport-specific patterns. PLoS One, 6(5), e19007. doi:10.1371/journal.pone.0019007

Scoffier, S., Maiano, C., \& D’Arripe-Longueville, F. (2010). The effects of social relationships and acceptance on disturbed eating attitudes in elite adolescent female athletes: The mediating role of physical self-perceptions. International Journal of Eating Disorders, 43(1), 65-71. doi:10.1002/eat.20597

Silva, L., Gomes, A. R., \& Martins, C. (2011). Psychological factors related to eating disordered behaviors: A study with Portuguese athletes. The Spanish Journal of Psychology, 14(1), 323-335. doi:10.5209/rev_SJOP.2011.v14.n1.29

Slaughter, M. H., Lohman, T. G., Boileau, R. A., Horswill, C. A., Stillman, R. J., Van Loan, M. D., \& Bemben, D. A. (1988). Skinfold equations for estimation of body fatness in children and youth. Human Biology, 60(5), 709-723.

Sundgot-Borgen, J., \& Torstveit, M. K. (2004). Prevalence of disorders in elite athletes in higher than in the general population. Clinical Journal of Sport Medicine, 14(1), 25-32.

Sundgot-Borgen, J., \& Torstveit, M. K. (2010). Aspects of disordered eating continuum in elite highintensity sports. Scandinavian Journal of Medicine \& Science in Sports, 20(Suppl. 2), 112-121. doi:10.1111/j.1600-0838.2010.01190.x

Teixeira, P. C., Hearst, N., Matsudo, S. M. M., Cordás, T. A., \& Conti, M. A. (2011). Adaptação transcultural: Tradução e validação de conteúdo da versão brasileira do Commitment Exercise Scale. Revista de Psiquiatria Clínica, 38(1), 24-28. doi:10.1590/S0101-60832011000100006 
Torstveit, M. K., \& Sundgot-Borgen, J. (2005). The female athlete triad exists in both elite athletes and controls. Medicine and Science in Sports and Exercise, 37(9), 1449-1459. doi:10.1249/01. mss.0000177678.73041.38

Leonardo de Sousa Fortes is a Professor of the Núcleo de Educação Física e Ciências do Esporte of the Universidade Federal de Pernambuco.

Sebastião de Sousa Almeida is a Full Professor of the Faculdade de Filosofia, Ciências e Letras de Ribeirão Preto of the Universidade de São Paulo.

Maria Elisa Caputo Ferreira is an Adjunct Professor of the Faculdade de Educação Física e Desportos of the Universidade Federal de Juiz de Fora.

Received: Sep. $21^{\text {st }}, 2012$

$1^{\text {st }}$ Revision: May $24^{\text {th }}, 2013$

Approved: Jul. $5^{\text {th }}, 2013$

How to cite this article:

Fortes, L. S., Almeida, S. S., \& Ferreira, M. E. C. (2014). Influence of psychological, anthropometric and sociodemographic factors on the symptoms of eating disorders in young athletes. Paidéia (Ribeirão Preto), 24(57), 21-28. doi:10.1590/1982-43272457201404 